\title{
METODE FORWARD CHAINING PADA SISTEM PAKAR DALAM MENDIAGNOSIS PENYAKIT KULIT
}

\author{
${ }^{[1]}$ Indyah Hartami Santi, ${ }^{[2]}$ Ardita Irvan Septiawan \\ ${ }^{[1]}$ Universitas Islam Balitar, ${ }^{[2]}$ Universitas Islam Balitar
}

\begin{abstract}
Abstrak: Kesehatan merupakan hal yang berharga bagi manusia karena siapa saja dapat mengalami gangguan kesehatan. Orang dewasa juga rentan terhadap berbagai macam penyakit. Penyakit kulit sering menyerang orang dewasa. Kulit merupakan organ terluar dan merupakan organ perlindungan pertama pada manusia sehingga jika terjadi sesuatu pada manusia maka organ yang lebih dahulu terkena adalah kulit. Ketersediaan seorang pakar masih terbatas dibandingkan dengan penderita yang mengalamai gangguan kulit. Sistem ini dirancang untuk dapat menirukan keahlian seorang pakar dalam menjawab pertanyaan dan menyelesaikan suatu permasalahan, khususnya di bidang kesehatan. Pemanfaatan teknologi dalam bidang kesehatan sangatlah perlu terutama dalam membantu tugas seorang pakar kulit. Penelitian sistem pakar ini bertujuan untuk mendiagnosis penyakit kulit dengan menggunakan metode fordward chaining berbasis web yang disertai dengan cara pencegahan dan pengobatannya.
\end{abstract}

Kata kunci : Sistem Pakar, Kulit, fordward chaining

\section{Pendahuluan}

Kesehatan kulit perlu diperhatikan karena kulit merupakan bagian yang paling vital serta merupakan cermin kesehatan dan kehidupan. Kulit adalah jaringan yang selama ini kurang diperhatikan oleh sebagian besar orang sampai terjadi sesuatu. Lalu, mereka baru menyadari betapa pentingnya kulit bagi citra diri. Dengan demikian, kulit pada manusia mempunyai peranan yang sangat penting, selain fungsi utama yang menjamin kelangsungan hidup juga mempunyai arti lain yaitu ras, dan sarana komunikasi nonverbal antar individu satu dengan yang lain. Banyak penyakit kulit menyebabkan gatal dan ketidaknyamanan untuk jangka waktu lama. Penyakit kulit dapat menyebabkan kegagalan fungsi kulit dan ini sama seriusnya dengan penyakit hati dan ginjal.

Peran dokter spesialis sangat diperlukan sekali di dalam dunia medis. Hambatan-hambatan yang menyebabkan sulitnya melakukan konsultasi penyakit dapat diatasi dengan adanya kemajuan teknologi. Pengetahuan-pengetahuan dan pengalaman mengenai penyakit dapat disimpan dalam program komputer yang nantinya dapat digunakan untuk melakukan konsultasi penyakit.

Penelitian terkait penyakit kulit telah dilakukan oleh beberapa peneliti diantaranya dilakukan oleh Doto(2010), Yastita (2012), Kusuma, (2010), Nurfitriyani dan fadilah (2012). Penelitian tersebut mengulas tentang penerapan sistem pakar dalam bidang kesehatan dengan menerapkan beberapa metode dalam sistem pakar.

Kecerdasan buatan berkembang sangat pesat. Sistem ini dirancang untuk dapat menirukan keahlian seorang pakar dalam menjawab pertanyaan dan menyelesaikan suatu permasalahan baik di bidang kesehatan khususnya di kesehatan kulit. Penelitian ini membahas bagaimana membangun suatu aplikasi sistem pakar untuk mendiagnosis penyakit kulit pada manusia yang dapat diakses oleh masyarakat luas tanpa membutuhkan biaya yang banyak dalam mendiagnosis penyakit kulit. 
Rumusan masalah dalam penelitian ini sebagai berikut. Pertama, bagaimanakah sebuah sistem pakar dapat bersifat user friendly sehingga dapat digunakan sebagai alat alternatif ke dua setelah ke dokter spesialis?. Kedua, bagaimanakah cara membangun aplikasi sistem pakar diagnosis penyakit kulit menggunakan metode Forward Chaining?

Batasan masalah dalam penelitian ini sebagai berikut. Pertama, penentuan jenis penyakit kulit berdasarkan gejala yang dialami. Kedua, penyakit kulit pada orang dewasa. Ketiga, hanya dibatasi pada 10 jenis penyakit kulit.

Tujuan dalam penelitian ini sebagai berikut. Pertama, untuk menciptakan aplikasi sistem pakar untuk diagnosis penyakit kulit yang berbasis web untuk memudahkan user dalam mendiagnosis penyakit kulit tanpa harus ke pakar. Kedua, untuk membuat sistem pakar menggunakan metode Forward Chaining yang dapat mendiagnosis penyakit kulit dari hasil pertanyaan yang sudah dijawab oleh user yang nantinya akan muncul hasil penyakitnya. Berkaitan dengan maslah dalam penelitian tersebut maka dipaparkan berbagai teori yang berkaitan dengan penelitian yang telah dilakukan sebagai berikut.

Sistem pakar adalah sistem berbasis komputer yang menggunakan pengetahuan, fakta, dan teknik penalaran dalam memecahkan masalah yang biasanya hanya dapat dipecahkan oleh seorang pakar dalam bidang tersebut (Kusrini, 2006). Sistem pakar memberikan nilai tambah pada teknologi untuk membantu dalam menangani era informasi yang semakin canggih. Sistem pakar hanya digunakan untuk memecahkan masalah yang memang sulit untuk dipecahkan dengan pemrograman biasa, mengingat biaya yang diperlukan untuk membuat sistem pakar jauh lebih besar dari pada pembuatan sistem biasa.

Forward Chaining merupakan suatu penalaran yang dimulai dari fakta untuk mendapatkan kesimpulan (conclusion) dari fakta tersebut. Forward chaining bisa dikatakan sebagai strategi inference yang bermula dari sejumlah fakta yang diketahui. Pencarian dilakukan dengan menggunakan rules yang premisnya cocok dengan fakta yang diketahui tersebut untuk memperoleh fakta baru dan melanjutkan proses hingga goal dicapai atau hingga sudah tidak ada rules lagi yang premisnya cocok dengan fakta yang diketahui maupun fakta yang diperoleh (Arhami, 2005).

Forward chaining bisa disebut juga runut maju atau pencarian yang dimotori data (data driven search). Jadi, pencarian dimulai dari premis-premis atau informasi masukan (if) dahulu kemudian menuju konklusi atau derived information (then). Forward Chaining berarti menggunakan himpunan aturan kondisi-aksi. Dalam metode ini, data digunakan untuk menentukan aturan mana yang akan dijalankan atau dengan menambahkan data ke memori kerja untuk diproses agar ditemukan suatu hasil.

Proses identifikasi jenis penyakit kulit dan gejalanya ini diambil berdasarkan informasi dan data-data mengenai segala jenis penyakit dan gejala - gejala yang ditimbulkan apabila didiagnosis mengidap penyakit tersebut. Data - data mengenai penyakit dan gejalanya ini didapat dari media internet, website kesehatan maupun blog mengenai kesehatan kulit. Data - data tersebut kemudian dikumpulkan dan dicocokan kebenaran datanya satu sama lain. Apabila data memiliki kesamaan di beberapa website, maka data merupakan data yang sesuai. Hal ini dikarenakan ketiadaan seorang pakar secara langsung yang dapat memberikan informasi - informasi akurat dan berdasarkan pengalamannya. Data-data yang diperoleh disajikan sebagai berikut.

Tabel 1.1 Gejala Penyakit Kulit dan Namanya

\begin{tabular}{|c|c|c|}
\hline No & Gejala & Penyakit \\
\hline \multirow{5}{*}{1} & Rasa gatal & \multirow{5}{*}{ Eksim } \\
\hline & Alergi & \\
\hline & Bersisik dan pecah - pecah & \\
\hline & Kemerah-merahan & \\
\hline & Terasa panas & \\
\hline 2 & Terasa gatal & Herpes \\
\hline
\end{tabular}




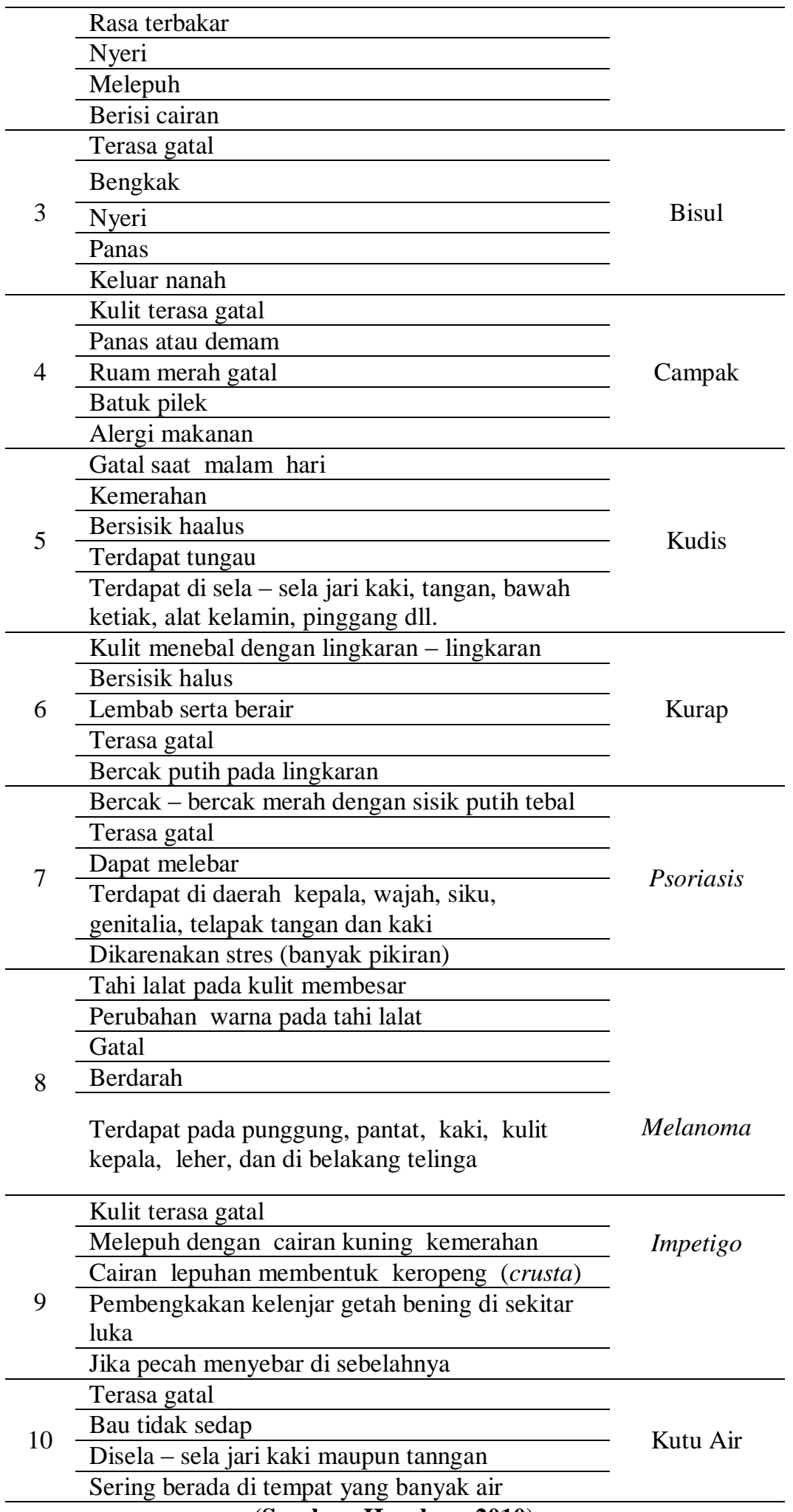

(Sumber: Harahap, 2010) 


\section{Metode Penelitian}

\section{A. Rancangan Basis Data}

Perancangan basis data pada sistem meliputi pembuatan tabel-tabel basis data. Perancangan sistem ini menggunakan teknik Entity Relationship Diagram (ERD) sebagai dasar pembuatan tabel-tabel basis data pada sistem ini. Di dalam database ini terdapat beberapa tabel. Adapun tabel-tabel yang terdapat pada perancangan sistem ini sebagai berikut.

\section{Tabel Diseases}

Tabel 2.1 adalah tabel diseases merupakan tabel data penyakit yang terdapat dalam aplikasi sistem pakar

TABEl 2.1 TABEL DiSEASES

\begin{tabular}{clll}
\hline No & \multicolumn{1}{c}{ Name } & \multicolumn{1}{c}{ Type } & Action \\
\hline 1 & Id & Int (11) & \\
\hline 2 & Code & Varchar (10) & Primary Key \\
\hline 3 & Name & $\begin{array}{l}\text { Varchar } \\
(200)\end{array}$ & Primary Key \\
\hline 4 & Description & Text & \\
\hline 5 & Img_url & Text & \\
\hline 6 & Img_dir & Text & \\
\hline 7 & Treatmend & Text & \\
\hline 8 & Updated_at & Datetime & Primary Key \\
\hline 9 & Created_at & Datetime & Primary Key \\
\hline
\end{tabular}

\section{Tabel Indications}

Tabel indications atau tabel gejala merupakan tabel yang berfungsi sebagai tempat untuk penyimpanan gejala-gejala dari sepuluh penyakit yang sudah ditentukan.

TABEL 2.2 TABEL INDICATIONS

\begin{tabular}{cllc}
\hline No & \multicolumn{1}{c}{ Name } & \multicolumn{1}{c}{ Type } & Action \\
\hline 1 & Id & Int (11) & \\
\hline 2 & Code & $\begin{array}{l}\text { Varchar } \\
(10)\end{array}$ & Primary Key \\
\hline 3 & Name & $\begin{array}{l}\text { Varchar } \\
(200)\end{array}$ & Primary Key \\
\hline 4 & Created_at & Datetime & Primary Key \\
\hline 5 & Updated_at & Datetime & Primary Key \\
\hline 6 & Deleted_at & Datetime & Primary Key \\
\hline
\end{tabular}

\section{Tabel maps}

Tabel 2.3 adalah tabel maps yang berfungsi untuk memetakan gejala-gejala penyakit sesuai dengan penyakitnya.

TABEL 2.3 TABEL MAPS

\begin{tabular}{clcc}
\hline No & \multicolumn{1}{c}{ Name } & Type & Action \\
\hline 1 & Id_diseases & Int $(11)$ & Primary Key \\
\hline 2 & Id_indications & Int (11) & Primary Key \\
\hline
\end{tabular}




\section{Tabel settings}

Tabel 2.4 adalah tabel yang berfungsi untuk menyunting isi halaman yang ada dalam palikasi sistem pakar penyakit kulit.

TABEL 2.4 TABEL SETTING

\begin{tabular}{cllc}
\hline No & Name & \multicolumn{1}{c}{ Type } & Action \\
\hline 1 & Code & Varchar (10) & \\
\hline 2 & Title & $\begin{array}{l}\text { Varchar } \\
(100)\end{array}$ & Primary Key \\
\hline 3 & Content & Text & \\
\hline 4 & Updated_at & Datetime & Primary Key \\
\hline
\end{tabular}

\section{Tabel Users}

Tabel 2.5 adalah tabel user yaitu tabel untuk admin masuk ke dalam halaman dashbosrd admin.

\section{TABEL 2.5 TABEL USERS}

\begin{tabular}{llll}
\hline No & \multicolumn{1}{c}{ Name } & \multicolumn{1}{c}{ Type } & Action \\
\hline 1 & Username & Varchar (20) & \\
\hline 2 & Name & Varchar (50) & Primary Key \\
\hline 3 & Type & Int (11) & Primary Key \\
\hline 4 & Pass & Varchar (50) & Primary Key \\
\hline 5 & Created_at & Datetime & Primary Key \\
\hline 6 & Updated_at & Datetime & Primary Key \\
\hline 7 & Last_login & Datetime & Primary Key \\
\hline 8 & Status & Tinyint (1) & Primary Key \\
\hline
\end{tabular}

\section{Tabel Histori}

Tabel 2.6 adalah tabel histori yang berfungsi untuk merekap hasil diagnosis yang dilakukan oleh user.

TABEL 2.6 TABEL HISTORI

\begin{tabular}{clll}
\hline No & \multicolumn{1}{c}{ Name } & \multicolumn{1}{c}{ Type } & Action \\
\hline 1 & Id & Int (11) & \\
\hline 2 & Nime & Varchar (50) & Primary Key \\
\hline 3 & Date & Timestamp & Primary Key \\
\hline 4 & Result & Int (11) & Primary Key \\
\hline
\end{tabular}

\section{B. Rancangan Entity Relationship Diagram (ERD)}

Relasi antar tabel menggambarkan hubungan antara tabel satu dengan tabel yang lain. Bentuk relasi pada sistem yaitu one to many, many to one, dan many to many. 


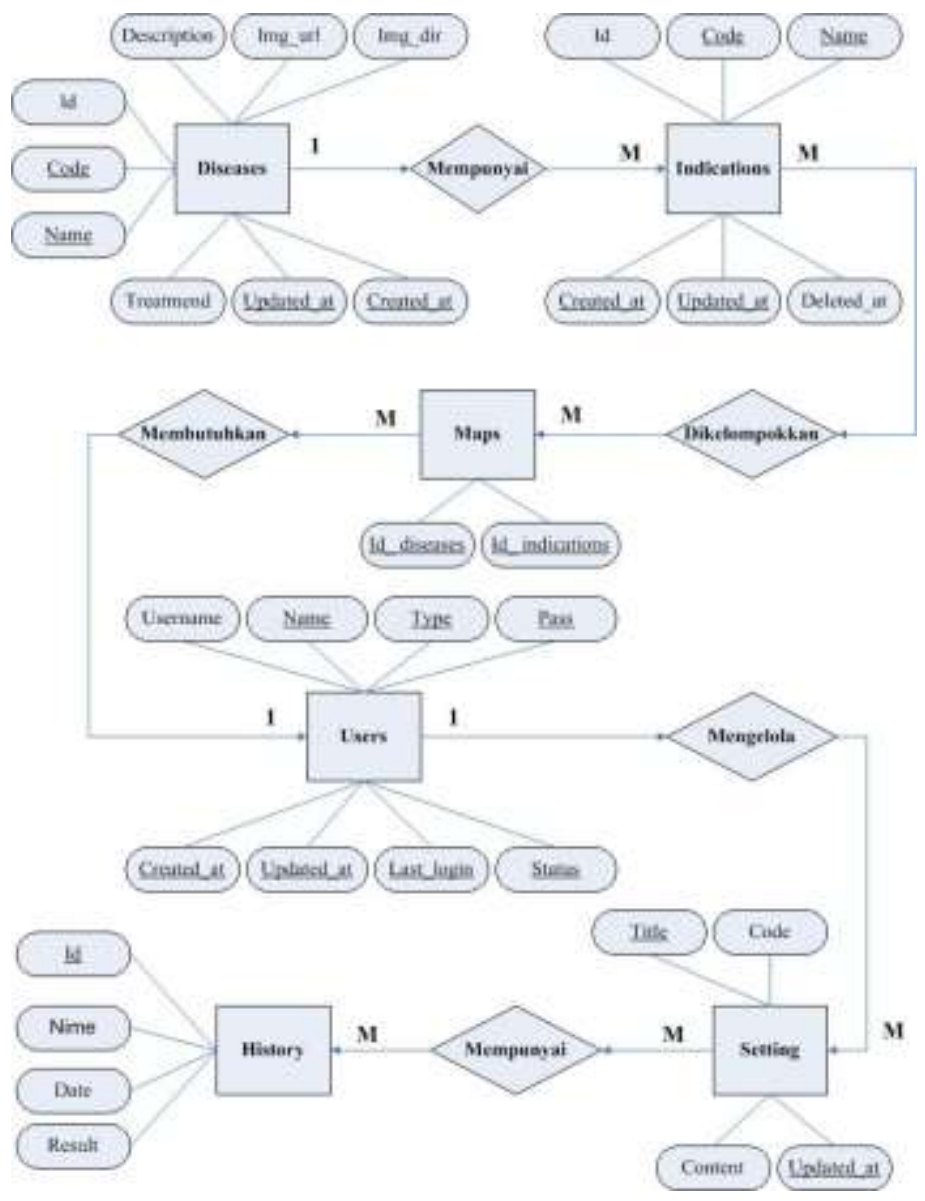

Gambar 2.1 Diagram Relasi Tabel

\section{Data Flow Diagram (DFD)}

Diagram Alir Data (DAD) atau Data Flow Diagram (DFD) adalah suatu diagram yang menggunakan notasi-notasi untuk menggambar kan arus dari data sistem yang penggunaannya sangat membantu untuk memahami sistem secara logika, tersruktur, dan jelas.

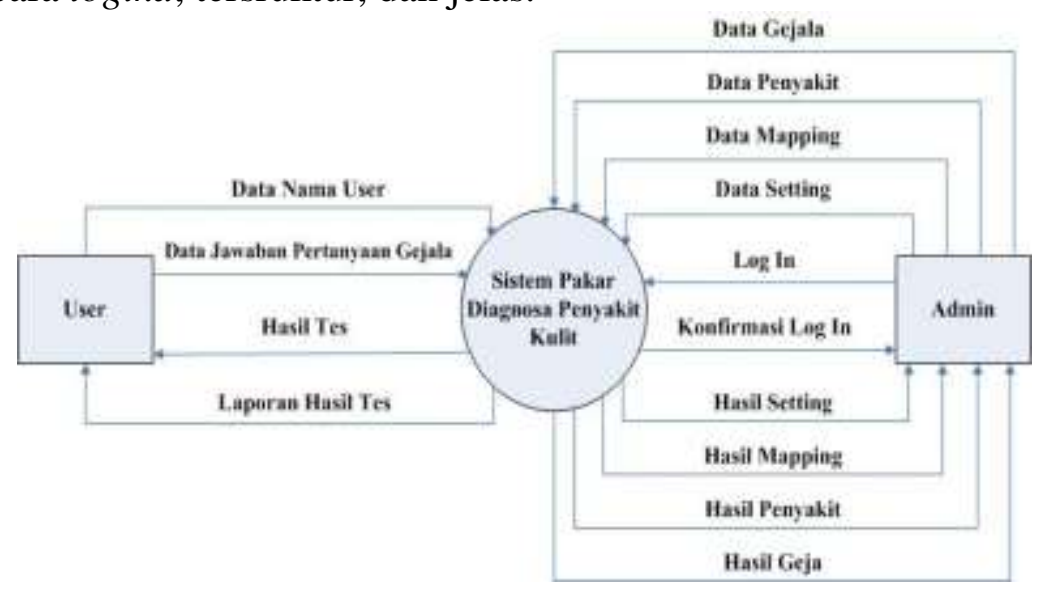

Gambar 2.2 DFD Level 0 


\section{DFD Level 1 Sistem Pakar Penyakit kulit}

Gambar 2.3 menggambarkan DFD level 1 arus yang terjadi dalam sistem pakar penyakit kulit.

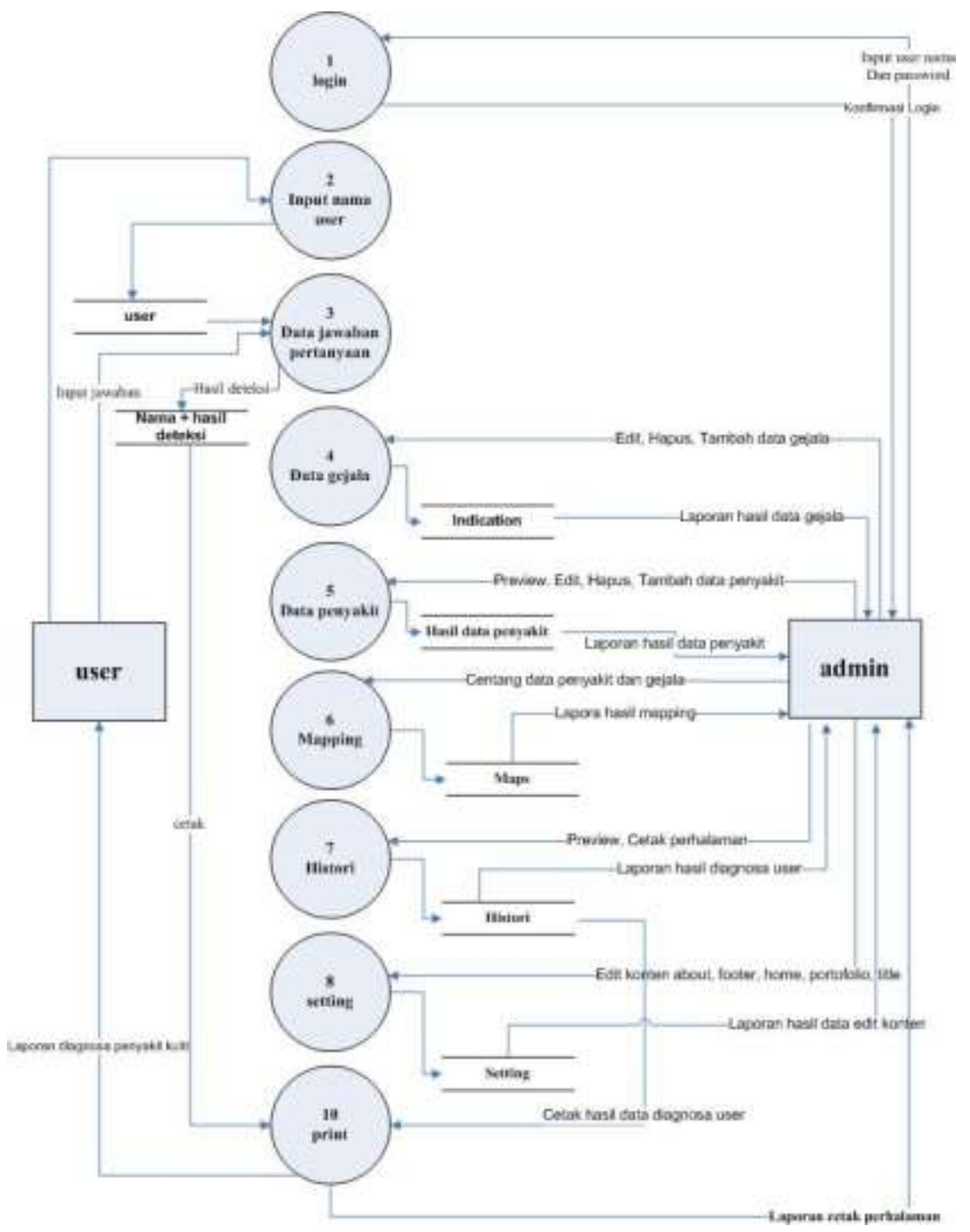

Gambar 2.3 DFD Level 1

\section{E. Flowchart Sistem}

Flowchart sistem dalah gambaran grafis yang memperlihatkan aliran data dari sumbernya dalam objek kemudian melewati suatu proses yang mentransformasikan ketujuan yang lain, yang ada pada objek lain.

\section{Flowchart Prosedur Login Admin}

Flowchart prosedur yang dilakukan admin untuk Login dalam sistem aplikasi ini digambarkan seperti pada gambar 2.4 berikut. 


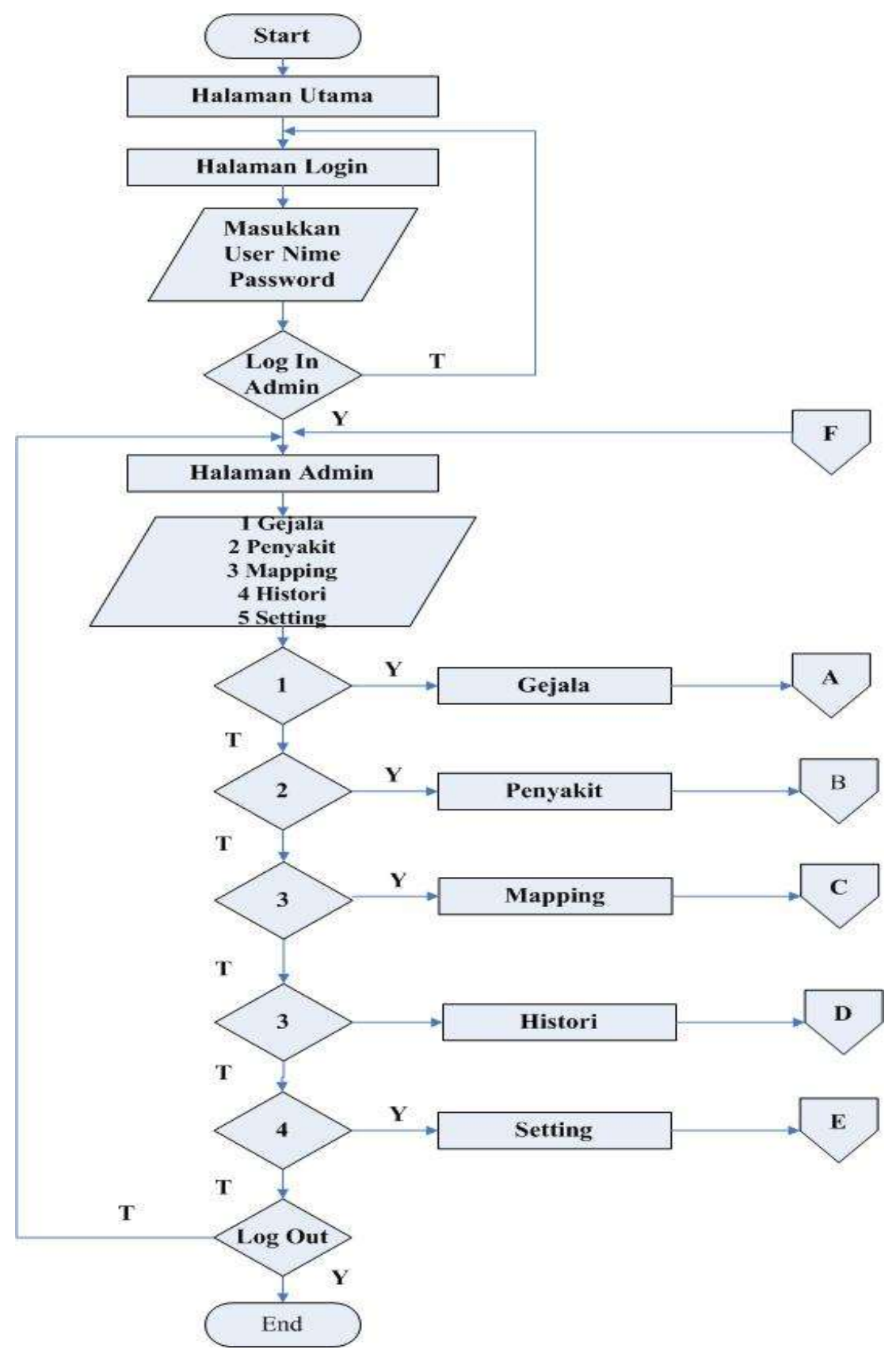

Gambar 2.4 Flowchart Login Admin

\section{Flowchart Prosedur Sistem Pakar Deteksi Penyakit Kulit}

Gambar 2.5 menggambarkan flowchart prosedur untuk user ketika menggunakan sistem ini. 


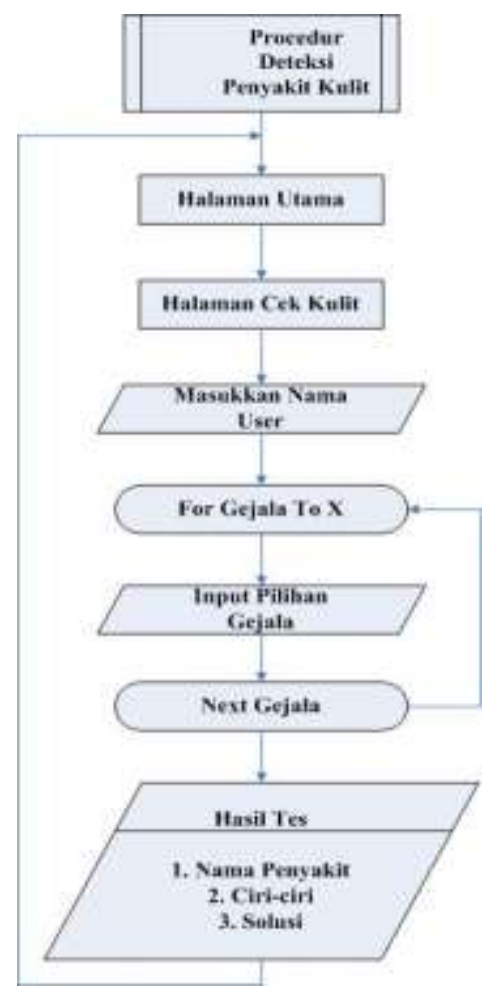

Gambar 2.5 Flowchart Prosedur Sistem Pakar Deteksi Penyakit Kulit

\section{Hasil dan Pembahasan}

\section{A. Tampilan Halaman User}

1. Tampilan Halaman Dashboard

Tampilan halaman dashboard pada sistem ditampilkan seperti pada gambar 3.1 berikut.

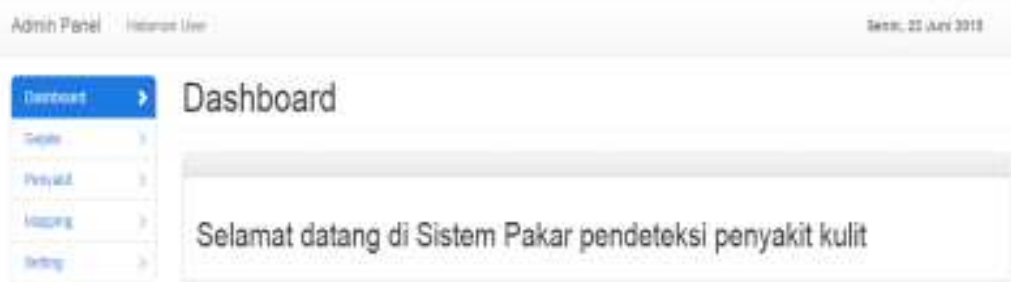

\section{Gambar 3.1 Tampilan Halaman Dashboard}

\section{Tampilan Halaman Gejala Cek Kulit}

Tampilan halaman gejala penyakit tersaji seperti pada gambar 3.2 berikut. 


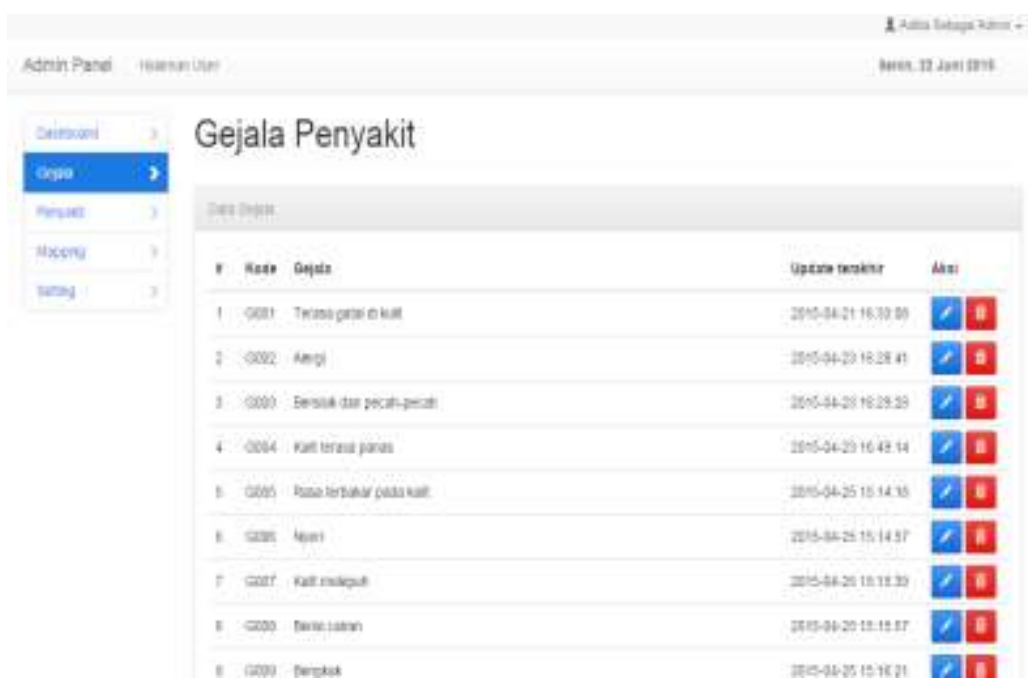

Gambar 3.2 Tampilan Halaman Gejala Cek Kulit

\section{Tampilan Halaman Penyakit}

Tampilan halaman penyakit tersaji seperti pada gambar 3.3 berikut .

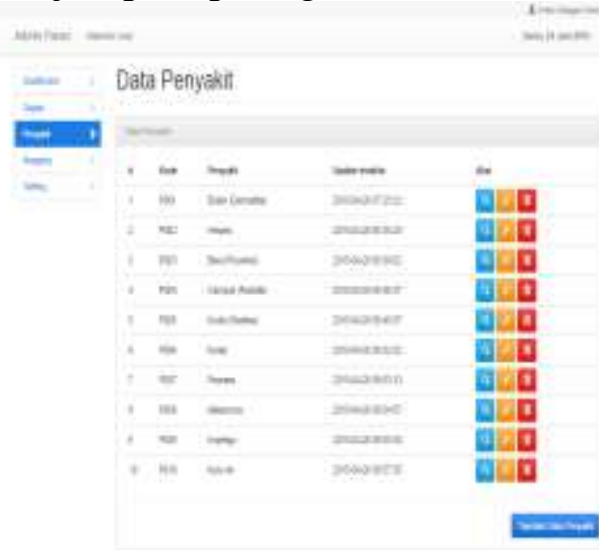

Gambar 3.3 Tampilan Halaman Penyakit

\section{Tampilan Halaman Mapping}

Tampilan halaman mapping tersaji seperti pada gambar 3.4 berikut. 


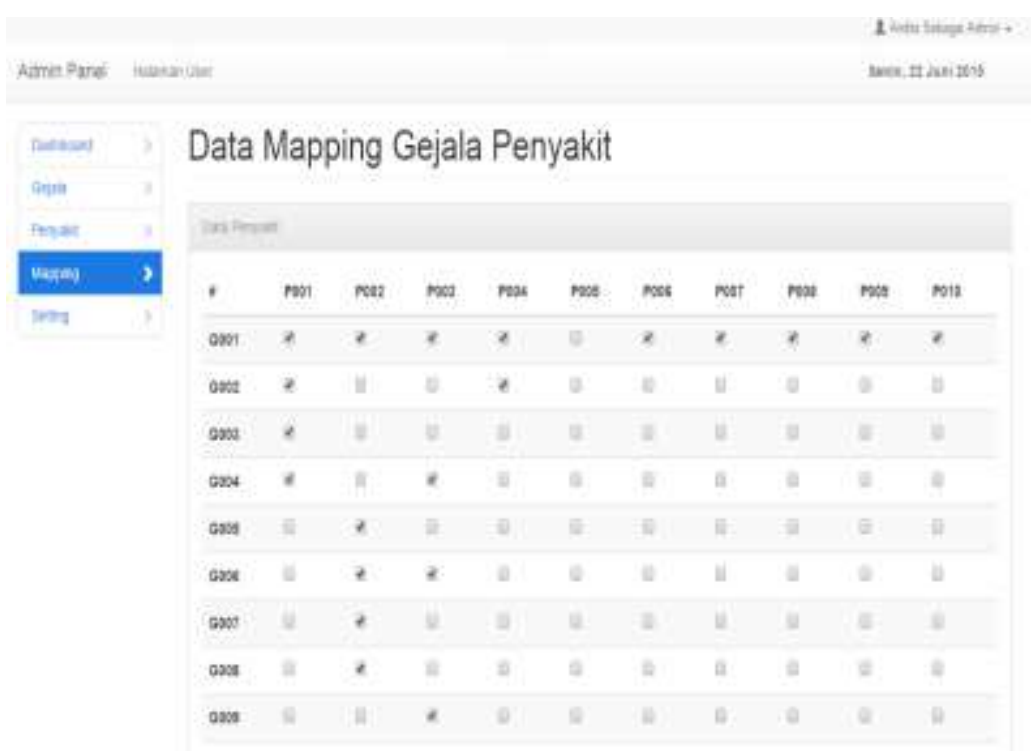

Gambar 3.4 Tampilan Halaman Mapping

\section{B. Pengujian Sistem}

Pengujian sistem ini dilakukan untuk mengetahui apakah sistem sudah berjalan sesuai dengan tujuan yang diinginkan. Tujuan utama dari pembuatan sistem ini adalah membuat sistem yang mampu mendiagnosis penyakit kulit. Pengujian sistem dilakukan terhadap orang dewasa sejumlah 100 kali percobaan pada waktu yang berbeda. Hasil pengujian tersebut dapat disajikan seperti pada tabel 3.1 berikut.

Tabel 3.1. Tabel Hasil UJI Coba Sistem

\begin{tabular}{clc}
\hline No. & \multicolumn{1}{c}{ Keterangan } & $\%$ \\
\hline 1 & $\begin{array}{l}\text { Hasil penyakit ada tetapi tidak sesuai } \\
\text { dengan gejalanya }\end{array}$ & 20 \\
\hline 2 & Hasil penyakit tidak ada & 10 \\
\hline 3 & $\begin{array}{l}\text { Hasil penyakit ada dan gejalanya } \\
\text { sesuai }\end{array}$ & 70 \\
\hline
\end{tabular}

Berdasarkan persentase di atas maka sistem pakar penyakit kulit ini dapat dijadikan sebagai referensi untuk user yang ingin mendiagnosis penyakit kulit. Selanjutnya, berdasarkan hasil pengujian perbandingan antara pakar kulit dengan sistem pakar penyakit kulit yaitu sistem pakar dengan metode forward chaining dapat menirukan diagnosis dari ahli atau pakar kulit. Hasil olahan aplikasi sistem pakar menunjukkan bahwa hasil sesuai 100\% seperti hasil analisis dari pakar yang dalam hal ini dr. A. Sony Purananda.

\section{Simpulan}

Simpulan penelitan sistem pakar ini adalah sebagai berikut.

1. Aplikasi yang dibangun dapat digunakan oleh pengguna untuk mendiagnosis penyakit kulit sebelum melakukan pemeriksaan lebih lanjut ke dokter ahli.

2. Membantu dalam melakukan identifikasi penyakit kulit secara dini, melalui pengolahan komputer, sehingga penanganan lebih lanjut terhadap penyakit tersebut dapat dengan cepat dilakukan.

3. Penggunan metode fordward chaining dengan proses penelusuran dapat digunakan untuk pembuatan Sistem Pakar Diagnosis Penyakit Kulit. 


\section{DAfTar Pustaka}

Arhami, M. 2005. Konsep Dasar Sistem Pakar. Yogyakarta: Andi Offset,.

Doto, D. 2010. Sistem Pakar untuk Mendiagnosis Penyakit Kulit dan Pengobatannya Menggunakan Centainty Factor. (online). ( http://journal.amikom.ac.id/index.php/SI/article/download/5076/2766 diakses 1 Januari 2018)

Evi, N. 2010. Sistem Pakar Diagnosis Penyakit Kulit pada Anak. (online). (jumadi.blog.ugm.ac.id/files/2012/05/Evi-Nurfitriani.pdf, diakses pada 13 Januari 2017)

Fadhilah, A.N., Destiani, D., dan Dhamiri, D.J. 2012. Perancangan Aplikasi Sistem Pakar Penyakit Kulit pada Anak dengan Metode Expert Sistem Development Life Cycle. Jurnal Algoritma Sekolah Tinggi Teknologi Garut ISSN : 2302-7339 Vol. 09 No. 132012

Harahap, M. 2000. Ilmu Penyakit Kulit. Jakarta: Hipokrotes.

Kusrini. 2006. Sistem Pakardan Teori Aplikasi. Yogyakarta: Andi Offset.

Kusuma, D.K., dan Febrianti D, 2010. Sistem Pakar untuk Diagnosis Penyakit Kulit Wajah.(online). (http://eprints.mdp.ac.id/317/1/SISTEM\%20PAKAR\%20UNTUK\%20DIAGNOSA\%20PENYAKI T\%20KULIT\%20WAJAH.pdf, diakses 23 Januari 2017)

Yastita,S., Lulu, Y.D., dan Sari, R.P. 2012. Sistem Pakar Penyakit Kulit pada Manusia Menggunakan Metode Certainty Factor Berbasis Web. Seminar Nasional Teknologi Informasi, Komunikasi dan Industri (SNTIKI) 4 ISSN : 2085-9902 